\title{
A escola do futuro
}

\section{The school of the future}

\section{La escuela del futuro}

Heberth Paulo de Souza

Katriane Stéfane Couto

Maria Eduarda Silveira Andrade

Centro Universitário Presidente Tancredo de Almeida Neves (Brasil)

PIANGERS, Marcos; BORBA, Gustavo. A escola do futuro: o que querem le precisam) alunos, pais e professores. Porto Alegre: Penso, 2019.

O livro intitulado "A escola do futuro", da autoria de Marcos Piangers e Gustavo Borba, traz o sugestivo subtítulo "o que querem (e precisam) alunos, pais e professores", e a partir daí mesmo já se apresenta com uma visão prospectiva sobre a instituição escolar. Essa co-autoria permite que a inserção acadêmica de Piangers na área de tecnologia, criatividade e inovação se alie aos conhecimentos técnicos de Borba como engenheiro e pesquisador em design e crie uma interface nessas áreas do conhecimento voltada para importantes discussões sobre o ensino. O livro chama a atenção do leitor, logo de início, pelo layout bastante inovador, repleto de símbolos ligados às tecnologias e mídias sociais, bem como a disposição do conteúdo num formato bastante próximo ao dessas mesmas mídias: fugindo da disposição canônica das sentenças e parágrafos, as ideias se desenvolvem em típico formato de hipertexto, no qual as palavras se mesclam ao visual repleto de infográficos, links e QR codes, bem nos moldes da comunicação interativa das redes sociais.

O livro se inicia abordando a evolução da escola ao longo do tempo. Mostra-se que, mesmo podendo ter mudado mais, o espaço escolar apresenta hoje diversos fatores que de certa forma ampliaram o acesso ao ensino no país, não apenas em termos de sua estrutura física, mas também pela introdução de temáticas transdisciplinares. Entretanto, em vez de esse processo ser encarado como uma forma natural de evolução, na realidade é visto com um sentimento 
de frustração por parte dos pais dos alunos, especialmente pela visão de que toda e qualquer iniciativa existente envolvendo inovação tecnológica já nasce "ultrapassada". Sobre esse aspecto, o autor do capítulo esclarece que a "[...] primeira coisa que precisamos reconhecer nessa discussão é que a escola nunca será um ambiente pronto; ela é, na verdade um espaço em constante evolução". (p. 30).

O livro aborda as mudanças ocorridas desde 1980, quando os estudantes realizavam atividades com pouquíssimo acesso ao conhecimento, até os dias atuais, quando o professor deixou de ter um papel de detentor do mesmo, e a relação com seus alunos passa a ser de forma horizontal, pois agora a maioria dos cidadãos possui acesso à informação de forma democrática - à clara exceção, bem apresentada na obra, daqueles que ainda se encontram à margem da sociedade digital.

Na sequência, Piangers discute os sentimentos dos pais em relação à alfabetização dos filhos, especialmente a forma como aqueles se sentem orgulhosos quando os filhos se desenvolvem rápido. De acordo com as pesquisas relatadas na obra, o fato de as crianças serem mais avançadas do que o esperado não garante sucesso no seu futuro. A partir disso, são apresentadas 2 algumas propostas para incentivar as crianças a desenvolver habilidades: entre elas, dizer à criança que ela está se esforçando, e não que ela é inteligente; manter na criança seu espírito de curiosidade, entre outras formas. Ainda assim, normalmente os pais ainda não se sentem satisfeitos com as escolas, o que thes propicia o sentimento de que em algum lugar existe uma instituição melhor do que aquela em que seus filhos estudam. Devido à grande quantidade de informações disponíveis, os pais se sentem perdidos e inseguros.

A escola passou por diversas mudanças ao longo do tempo, porém não no ritmo que se esperava. Assim, alguns pais acabaram optando pelo ensino em casa (homeschooling). Embora esse tipo de ensino não seja legalizado no Brasil, existem diversas plataformas que disponibilizam metodologias próprias para essa prática. De acordo com o autor do capítulo, esse meio de ensino exige do estudante um senso de responsabilidade pessoal, automotivação e desejo de aprender; por outro lado, são muitas as críticas que o modelo recebe, especialmente no tocante à ausência da socialização do aluno nesse método. 
Também, é desenvolvida a temática envolvendo os professores, que historicamente foram vinculados à figura de sábios, detentores de conhecimentos sobre diversas áreas do conhecimento e possuindo a função de propagá-los para os alunos, de forma a gerar transformação em todos. Esse papel não sofreu alterações ao longo do tempo; porém, devido aos acontecimentos a partir do século XX como a globalização, acesso à informação, surgimento da Internet e de novas tecnologias, culminou-se na sua mudança. A figura do professor tornou-se ainda mais importante, assumindo papéis diferenciados dentro e fora da sala de aula, que se desdobram em eixos que pressupõem o acesso às informações pelos alunos e a ligação de tais com o conteúdo abordado em sala, como também uma ação de mentoria que envolve o cuidado, a liderança, a cooperação e a conexão para aperfeiçoar o conhecimento.

E ainda, a partir das modificações na função docente, é mencionada a necessidade do desenvolvimento de competências indispensáveis à profissão. Assim, com a exposição de artigos e estudos referentes a todos os temas, são identificadas e detalhadas competências que ampliam o repertório relacionado à compreensão de tais, exigindo do professor o repensar do seu papel e construir um espaço de aprendizagem interativo, conexo e de fato relevante.

Na continuidade do livro, é evidenciada a questão do perfil dos alunos da atualidade e o impacto que estes ocasionaram na transformação digital da sala de aula e dos processos de aprendizagem devido à chegada de jovens da geração $Z$ ao ensino superior. Os discentes da geração atual, conhecidos como nativos digitais, têm características marcantes - entre elas a forma diferenciada de aprender. À vista disso, com o aporte de várias pesquisas, apresenta-se que a aquisição de conhecimentos somente será significativa se for acompanhada da atividade prática, uso de metodologias ativas e interação, permitindo maior troca e conexão entre os alunos. Ao considerar esse cenário, é exposta a necessidade urgente de abandonar modelos antigos que já são inviáveis no século XXI e difundir a necessidade de uma adaptação e alteração na forma de atuar dos professores.

A partir de estudos de Scott (2015) citados por Borba, este autor menciona competências e habilidades que precisam ser formadas nos alunos para o século atual. No contexto do Brasil, são descritas as competências para melhor formação dos educandos, relacionadas à ałuação em meios que vão além do profissional, abrangendo também áreas sociais definidas como competências transversais, tornando-se imprescindível identificar tais competências 
no contexto de inserção dos alunos, bem como a adaptação, flexibilidade e valorização da diversidade de situações.

No último capítulo do livro, Piangers trata do aspecto mais esperado da publicação, coroando todo o percurso histórico e as considerações e críticas apresentadas no decorrer dos capítulos anteriores: como será a escola do futuro. Partindo da Lei de Moore, publicada em meados do século XX, através da qual se pode prever a capacidade que um processador eletrônico poderá ter nas próximas décadas, estima-se que um chip chegará perto da capacidade de um cérebro humano por volta de 2029; que por volta de 2045 seremos capazes de plugar nossos cérebros em máquinas inteligentes; que será possível dobrar o nosso índice de aprendizado com a utilização de estímulos transcranianos; e que acontecerão várias outras mudanças através do processo de aprendizado da máquina.

Muito dessa realidade futurista já existe no nosso quotidiano: as redes sociais e sistemas fechados de televisão, por exemplo, já "aprendem" com o nosso uso, direcionando-nos para o que estamos pensando ou procurando; lousas interativas e hologramas já não são novidades no meio educacional. Daí a urgência e a necessidade de se repensar o modelo de ensino, sempre.

Por fim, vale ressaltar que o conhecimento socializado pelos autores é de extrema relevância na conjuntura do atual sistema educacional do Brasil e do mundo, apresentando esse livro possibilidades de leitura e de debate altamente recomendáveis para todas as pessoas que, de uma forma ou de outra, estão ligadas ao processo de ensino-aprendizagem, em todos os níveis e em todas as modalidades de ensino.

Prof. Dr. Heberth Paulo de Souza Centro Universitário Presidente Tancredo de Almeida Neves (Brasil) Universidade Federal de Minas Gerais (Brasil) Orcid id: 0000-000 1-8657-8126 E-mail: hp.souza@globo.com 
Katriane Stéfane Couto

Centro Universitário Presidente Tancredo de Almeida Neves (Brasil)

Graduanda em Pedagogia Orcid id: 0000-000 1-6828-2559

E-mail:kcouto97@gmail.com

Maria Eduarda Silveira Andrade Centro Universitário Presidente Tancredo de Almeida Neves (Brasil)

Graduanda em Pedagogia Orcid id: 0000-000 1-6988-0884 E-mail: andrade.maria2000@hotmail.com

Recebido 21 jul. 2020

Aceito 29 jul. 2020 